\title{
HIPONATREMIA SEBAGAI PREDIKTOR PROGNOSIS KEMATIAN PASIEN CEDERA OTAK AKIBAT TRAUMA DI RUMAH SAKIT UMUM PUSAT (RSUP) DR. SARDJITO YOGYAKARTA
}

\author{
Mariesta Kusumaningtyas, Atitya Fithri Khairani, Indarwati Setyaningsih
}

Departemen Neurologi, FK Universitas Gadjah Mada/RSUP Dr. Sardjito, Yogyakarta, Indonesia

Diterima 11 Agustus 2017

Disetujui 5 Mei 2018

Publikasi 21 Mei 2018

Korespondensi:dr.mariesta@gmail.com
Cara merujuk artikel ini: Kusumaningtyas (et al). 2018.

Hiponatremia Sebagai Prediktor Prognosis Kematian

Pasien Cedera Otak Akibat Trauma di Rumah Sakit Umum Pusat (RSUP) dr. Sardjito Yogyakarta. Callosum Neurology Journal 1(2):73-77. DOI: https://doi.org/10.29342/cnj.vli2.37

\begin{abstract}
ABSTRAK
Latar Belakang: Hiponatremia merupakan gangguan elektrolit yang paling sering terjadi pada pasien cedera otak akibat trauma yang dapat memperburuk kondisi dan dapat menjadi salah satu penyebab disabilitas/ mortalitas. Tujuan: Untuk menilai hubungan hiponatremia terhadap prognosis kematian pasien cedera otak akibat trauma di Rumah Sakit Umum Pusat (RSUP) Dr. Sardjito Yogyakarta.

Metode: Penelitian analitis menggunakan metode potong lintang terhadap data rekam medis pasiencedera otak akibat trauma di RSUP Dr. Sardjito selama bulan
\end{abstract}

\section{Desember 2016.}

Hasil: Jumlah pasien meninggal sebanyak 13,5\%. Kadar natrium berpengaruh terhadap prognosis kematian pada pasien cedera otak akibat trauma $(\mathrm{p}=0,031)$.

Simpulan: Hiponatremia berhubungan dengan prognosis kematian pasien cedera otak akibat trauma di RSUP Dr. Sardjito Yogyakarta.

Kata Kunci: Hiponatremia, Cedera otak akibat trauma, Prognosis, Mortalitas

\begin{abstract}
Background: Hyponatremia is an electrolyte imbalance most often occurred among TBI patients and one of the main causes of disability and/or mortality in TBI patients.

Purpose: To determine the correlation of hyponatremia and mortality prognostic in TBI patients in Dr. Sardjito Hospital Yogyakarta.

Method: Analytic cross-sectional study of TBI patients in Dr. Sardjito Hospital Yogyakarta December 2016 from the medical record.
\end{abstract}

Result: Mortality rate was $13,5 \%$. The natrium level is related to mortality prognosis in TBI patients $(\mathrm{p}=0,031)$.

Conclusion: Hyponatremia is related to morbidity prognosis of TBI patients in Dr. Sardjito Hospital Yogyakarta

Keywords: Hyponatremia, Traumatic brain injury, Prognosis, Mortality 


\section{Latar Belakang}

Cedera kepala mengenai hampir 1,5 juta orang di Amerika Serikat setiap tahunnya dengan 240.000 orang membutuhkan rawat inap di rumah sakit. Sekitar 60.000 orang meninggal dan 70.000 orang mengalami cacat neurologis permanen. Estimasi kerugian finansial karena hilangnya produktivitas serta biaya perawatan medis berkisar 100 milyar dolar Amerika pertahunnya. ${ }^{1}$

Salah satu faktor ekstrakranial yang memperburuk prognosis pasien cedera kepala adalah hiponatremia. Kondisi hiponatremia selama masa perawatan berhubungan dengan cedera kepala. Sebuah penelitian retrospektif menunjukkan hiponatremia terjadi pada $16,8 \%$ pasien cedera kepala, 50,7\% pasien hematoma subdural (SDH), $25 \%$ pasien hematoma epidural (EDH), 47,9\% pasien kontusio cerebri, dan $50 \%$ pasien diffuse axonal injury (DAI). Terdapat korelasi antara kondisi hiponatremia dengan lama perawatan di rumah sakit serta luaran yang buruk. Kadar natrium serum menunjukan hubungan berbentuk $\mathrm{U}$ dengan luaran, yaitu semakin rendah atau tinggi kadar natrium, luaran cedera kepala semakin buruk.

Hiponatremia pascacedera kepala mengakibatkan gangguan homeostasis di sistem saraf pusat. Cedera kepala menyebabkan respons stres dan aktivasi aksis hipotalamus-hipofisis-adrenal yang meningkatkan atrial natriuretic peptide (ANP), brain natriuretic peptide (BNP), dan arginin vasopressin sehingga terjadi kondisi hiponatremia. Sekresi hormon antidiuretik (ADH) berlebihan, restriksi cairan, perdarahan, atau adanya cedera lain mengakibatkan terjadinya kondsi hipovolemia. Sekresi ADH berlebih sesuai untuk kondisi hipovolemia tetapi tidak sesuai untuk kondisi hiponatremia. Restriksi cairan dapat memperburuk kondisi dengan terus meningkatkan produksi ADH. Hiponatremia juga dapat terjadi karena kelebihan penggunaan cairan dekstrosa tanpa pemberian suplementasi natrium.

Hiponatremia yang tidak terkoreksi dapat memicu penurunan kesadaran dan kejang. Mekanismenya melalui timbulnya edema serebri, kematian sel otak, dan meningkatnya tekanan intrakranial yang menyebabkan herniasi dan kematian pasien. Hiponatremia memiliki tingkat morbiditas dan mortalitas yang tinggi, yaitu $17,9 \%$ pada pasien rawat inap. Studi lain menunjukkan angka mortalitas sebanyak $50 \%$ pada kadar natrium serum $<115 \mathrm{mmol} / \mathrm{L}, 25 \%$ pada kadar $<125 \mathrm{mmol} / \mathrm{L}$ setelah evaluasi selama 6 bulan. ${ }^{2}$

Penelitian mengenai hiponatremia pada pasien dengan cedera otak akibat trauma belum banyak dilakukan di Indonesia. Dengan alasan tersebut perlu dilakukan penelitian tentang hiponatremia sebagai prediktor prognosis kematian pasien cedera otak akibat trauma di RSUP Dr. Sardjito Yogyakarta.

\section{Metode Penelitian}

Penelitian ini menggunakan metode potong lintang dengan subyek penelitian semua rekam medis pasien yang termasuk dalam diagnosis cedera otak akibat trauma di Instalasi Catatan Medis RSUP Dr. Sardjito, Yogyakarta pada Desember 2016. Diagnosis cedera otak akibat trauma sesuai International Classification of Diseases (ICD) 10 meliputi traumatic cerebral oedema (S06.1), traumatic subdural haemorrhage (S06.5), traumatic subarachnoid haemorrhage (S06.6) yang dikonfirmasi dengan Computed Tomography (CT) sken kepala, dan dilakukan pemeriksaan natrium pada awal masuk rumah sakit. Hasil CT Sken kepala berupa tumor atau massa akan dieksklusi. Stratifikasi hiponatremia menjadi derajat ringan (131-135 mmol/L), sedang $(120-130 \mathrm{mmol} / \mathrm{L})$ dan berat $(<120 \mathrm{mmol} / \mathrm{L})$. Evaluasi juga dilakukan terhadap variabel usia, jenis kelamin, tingkat kesadaran, serta tindakan operatif. Analisis bivariat menggunakan uji Chi-Square karena seluruh variabel menggunakan skala kategorik.

\section{Hasil Penelitian}

Sebanyak 52 pasien cedera otak akibat trauma yang memenuhi kriteria penelitian dan menjalani rawat inap di RSUP Dr. Sardjito, Yogyakarta. Penilaian derajat kesadaran menggunakan Glasgow Coma Scale (GCS) dan dibagi menjadi 3 kategori, yaitu: (1) pasien sadar atau penurunan kesadaran ringan (GCS 14-15) sebanyak 8 (15,3\%) subjek, (2) pasien dengan penurunan kesadaran sedang (GCS 9-13) sebanyak $37(71,1 \%)$ subjek, (3) pasien dengan penurunan kesadaran berat (GCS 3-8) sebanyak 7 $(13,4 \%)$ subjek. Rerata GCS adalah 10.2 dengan $\mathrm{SD} \pm$ 3.27. Pemeriksaan elektrolit dilakukan saat 
pertama kali masuk rumah sakit. Rerata penurunan sebanyak $32(61,5 \%)$ subjek, dan derajat berat kadar natrium adalah 124,15 dengan $\mathrm{SD} \pm 10,11$. sebanyak $5 \quad(9,6 \%)$ subjek. Data demografis Ditemukan kondisi hiponatremia derajat ringan ditunjukkan oleh tabel 1. sebanyak $15 \quad(28,8 \%)$ subjek, derajat sedang

Tabel 1. Karakteristik Demografi Subjek Penelitian

\begin{tabular}{|c|c|c|c|c|c|}
\hline \multirow{2}{*}{ Data Demografis } & \multirow{2}{*}{ Jumlah (\%) } & \multirow{2}{*}{ Rerata \pm SD } & \multicolumn{2}{|c|}{$95 \%$ IK } & \multirow{2}{*}{ Nilai $_{1}$} \\
\hline & & & Bawah & Atas & \\
\hline Usia & & $31,79 \pm 5,66$ & 26,13 & 37,45 & 0,000 \\
\hline$<45$ tahun & $36(69,2 \%)$ & & & & \\
\hline$\geq 45$ tahun & $16(30,8 \%)$ & & & & \\
\hline \multicolumn{6}{|l|}{ Jenis kelamin } \\
\hline Laki-laki & $40(76,9 \%)$ & & & & \\
\hline Perempuan & $12(23,1 \%)$ & & & & \\
\hline Tingkat kesadaran & & $10,2 \pm 3,27$ & 6,93 & 12,57 & 0,000 \\
\hline Ringan & $8(15,5 \%)$ & & & & \\
\hline Sedang dan berat & $44(84,5 \%)$ & & & & \\
\hline Hiponatremia & & $124,15 \pm 10,11$ & 114,04 & 134,26 & 0,000 \\
\hline Ringan & $15(28,8 \%)$ & & & & \\
\hline Sedang dan berat & $37(71,1 \%)$ & & & & \\
\hline \multicolumn{6}{|l|}{ Tindakan operasi } \\
\hline $\mathrm{Ya}$ & $11(21,1 \%)$ & & & & \\
\hline Tidak & $41(78,8 \%)$ & & & & \\
\hline \multicolumn{6}{|l|}{ Prognosis } \\
\hline Hidup & $45(86,5 \%)$ & & & & \\
\hline Meninggal & $7(13,5 \%)$ & & & & \\
\hline
\end{tabular}

Keterangan: Standar Deviasi (SD), Indeks Kepercayaan (IK)

Tabel 1. Analisis Bivariat Variabel terhadap Prognosis

\begin{tabular}{|c|c|c|c|c|c|c|}
\hline \multirow{2}{*}{ Karakteristik Pasien } & \multirow{2}{*}{ Jumlah (\%) } & \multicolumn{2}{|c|}{ Prognosis } & \multirow{2}{*}{$\mathrm{RR}$} & \multirow{2}{*}{$95 \%$ IK } & \multirow{2}{*}{ Nilai $p$} \\
\hline & & Meninggal & Hidup & & & \\
\hline \multicolumn{7}{|l|}{ Usia } \\
\hline$<45$ tahun & $36(69,2 \%)$ & $3(6,9 \%)$ & $40(93 \%)$ & \multirow{2}{*}{1,65} & \multirow[t]{2}{*}{$0,431-6,313$} & \multirow[t]{2}{*}{0,147} \\
\hline$\geq 45$ tahun & $16(30,8 \%)$ & $4(44,4 \%)$ & $5(55,5 \%)$ & & & \\
\hline \multicolumn{7}{|l|}{ Jenis kelamin } \\
\hline Laki-laki & $40(76,9 \%)$ & $5(12,5 \%)$ & $35(87,5 \%)$ & \multirow{2}{*}{0,962} & \multirow[t]{2}{*}{$0,255-3,630$} & \multirow[t]{2}{*}{0,611} \\
\hline Perempuan & $12(23,1 \%)$ & $2(16,6 \%)$ & $10(83,3 \%)$ & & & \\
\hline \multicolumn{7}{|l|}{ Tingkat kesadaran } \\
\hline Ringan & $8(15,5 \%)$ & $4(50 \%)$ & $4(50 \%)$ & \multirow{2}{*}{0,498} & \multirow[t]{2}{*}{$0,489-0,958$} & \multirow[t]{2}{*}{0,067} \\
\hline Sedang dan berat & $44(84,5 \%)$ & $3(6,8 \%)$ & $41(93,1 \%)$ & & & \\
\hline \multicolumn{7}{|l|}{ Hiponatremia } \\
\hline Ringan & $15(28,8 \%)$ & $1(6,7 \%)$ & $6(93,3 \%)$ & \multirow{2}{*}{3,636} & \multirow[t]{2}{*}{$0,040-4,578$} & \multirow[t]{2}{*}{$0,031 *$} \\
\hline Sedang dan berat & $37(71,1 \%)$ & $6(16,2 \%)$ & $31(83,7 \%)$ & & & \\
\hline \multicolumn{7}{|l|}{ Tindakan operasi } \\
\hline $\mathrm{Ya}$ & $11(21,1 \%)$ & $3(27,2 \%)$ & $8(72,7 \%)$ & \multirow{2}{*}{0,427} & \multirow[t]{2}{*}{$0,330-7,769$} & \multirow[t]{2}{*}{0,427} \\
\hline Tidak & $41(78,8 \%)$ & $4(9,7 \%)$ & $37(90,2 \%)$ & & & \\
\hline
\end{tabular}

Keterangan $(*)$ korelasi bermakna pada nilai 0,05. Indeks Kepercayaan (IK), Risiko Relatif (RR) 
Hasil analisis bivariat terhadap prognosis pasien menunjukkan bahwa kadar hiponatremia berpengaruh terhadap kematian pasien cedera otak akibat trauma. Uji Chi-Square menunjukkan nilai $\mathrm{p}=0,031$.

Penelitian ini didominasi pasien berjenis kelamin laki-laki dibandingkan perempuan. Hasil ini sesuai dengan penelitian yang dilakukan Xiaofeng (2016) dengan proporsi subjek laki-laki adalah $60 \%$ dan subjek perempuan $40 \%{ }^{3}$

Rerata dan sebaran kelompok usia menunjukkan cedera otak akibat trauma dominan terjadi pada usia yang relatif muda. Hal ini disebabkan karena mobilitas yang tinggi di kalangan usia produktif sedangkan kesadaran untuk menjaga keselamatan di jalan masih rendah disamping penanganan pertama yang belum benar dan rujukan yang terlambat. Kasus trauma terbanyak disebabkan oleh kecelakaan lalu lintas, disamping kecelakaan industri, kecelakaan olahraga, jatuh dari ketinggian maupun akibat kekerasan. ${ }^{3}$ Tingkat kesadaran yang buruk pada mayoritas subjek serta tindakan operasi yang dilakukan tidak bermakna terhadap prognosis kematian pasien cedera otak akibat trauma. Hal ini sesuai dengan penelitian sebelumnya oleh Xiaofeng (2016), yang menyebutkan bahwa tidak ada hubungan antara usia, jenis kelamin, GCS, dan tindakan operasi terhadap terjadinya hiponatremia yang akan memperparah kondisi sehingga dapat menyebabkan terjadinya kematian. Dong dkk. (2012) meneliti prevalensi hiponatremia pada pasien dengan cedera medula spinalis segmen servikalis dan menemukan bahwa 38\% pasien menderita hiponatremia. ${ }^{4}$ Serupa dengan penelitian Xiaofeng (2016) penelitian ini, tidak ada hubungan antara usia, jenis kelamin, serta tindakan pembedahan terhadap mortalitas pasien.

\section{Daftar Rujukan}

1. Marik PE, Varon J, Trask T. Management of head trauma. Chest. 2002;122(2):699-711.

Clayton JA, Le-Jeune IR, Hall IP. Severe hyponatremia in medical in-patients; aetiology, assessment and outcome. QJM. 2006;99(8):505- 511.
Kondisi hiponatremia tersebut bila tidak didiagnosis dan ditangani sedini mungkin akan memperparah kondisi pasien hingga menyebabkan kematian.,5 Koreksi hiponatremia pada pasien cedera otak akibat trauma sangat penting. Rendahnya asupan natrium dapat dikoreksi dengan pemberian natrium tambahan secara oral atau intravena. Koreksi terhadap pola konsumsi diuretik yang berlebihan dengan cara mengurangi pemberian diuretik. Manajemen pasien dengan Syndrome of Inappropriate Antidiuretic Hormone Secretion (SIADH) berupa mengurangi asupan cairan, pemberian suplemen natrium, pemberian diuretic, dan/ atau pemberian albumin. Penatalaksanaan pasien dengan cerebral saltwasting syndrome (CSWS) dengan pemberian transfusi darah, suplemen natrium, dan terapi steroid jangka pendek. ${ }^{7,8}$

Hasil analitis bivariat kondisi hiponatremia mempengaruhi prognosis kematian pada pasien cedera otak akibat trauma di RSUP Dr. Sardjito Yogyakarta. Keterbatasan penelitian ini berupa kesulitan untuk menganalisis dan mengidentifikasi perjalanan penyakit pasien terkait kondisi hiponateremia yang mungkin dimiliki. Kondisi seperti seperti insufisiensi asupan natrium, kelebihan pemberian diuretik, SIADH, CSWS, dan diabetes insipidus potensial memperburuk kondisi dan meningkatkan risiko kematian pasien cedera otak akibat trauma.

\section{Simpulan}

Hiponatremia mempengaruhi prognosis kematian pasien cedera otak akibat trauma di RSUP Dr. Sardjito Yogyakarta.

2. Xiaofeng M, Baozhong S. Traumatic Brain Injury Patients with a Glasgow Coma Scale Score of $\leq 8$, Cerebral Edema, and/or a Basal Skull Fracture are More Susceptible to Developing Hyponatremia. J Neurosurg Anesthesiol. 2016;28(1):21-26. 
3. Dong YX, Wang XW, Wang L. Clinical analysis and management of hyponatremia in neurosurgical patients. Chin $\mathrm{J}$ Neurosurg. 2012;28:1160-1162.

4. Sajadieh A, Binici Z, Mouridsen MR, Nielsen OW, Hansen JF, Haugaard SB. Mild hyponatremia carries a poor prognosis in community subjects. Am J Med. 2009;122:679-686.
5. Waikar SS, Mount DB, Curhan GC. Mortality after hospitalization with mild, moderate, and severe hyponatremia. Am J Med. 2009;122:857-865.

6. Dhar R, Murphy-Human T. A bolus of conivaptan lowers intracranial pressure in a patient with hyponatremia after traumatic brain injury. Neurocrit Care. 2011;14:97-102.

7. Wu ZD, Wu ZH. Surgery. 7th ed. Beijing: People's Medical Publishing House. 